\title{
The El Masnou infralittoral sedimentary environment (Barcelona province, NW Mediterranean Sea): morphology and Holocene seismic stratigraphy
}

\author{
GEMMA ERCILLA, FERRAN ESTRADA, DAVID CASAS, RUTH DURÀN, \\ MARTA NUEZ, BELÉN ALONSO and MARCEL·LÍ FARRÁN \\ Institut de Ciències del Mar, CSIC, Grup de Marges Continentals. Passeig Marítim de la Barceloneta, 37-49. \\ 08003, Barclona, Spain. E-mail: gemma@icm.csic.es
}

\begin{abstract}
SUMMARY: A detailed analysis of the morphology and the Holocene seismic and sequence stratigraphy and architecture of the infralittoral sedimentary environment of the El Masnou coast (Catalonia, NW Mediterranean Sea) was carried out using multibeam bathymetry and GeoPulse seismic data. This environment extends down to 26-30 m water depth, and is defined morphologically by two depositional wedges whose seafloor is affected by erosive furrows, slides, fields of large- and smallscale wavy bedforms, and dredging trenches and pits. Erosive terraces are also identified in the transition domain toward the inner continental shelf. The Holocene stratigraphy of the infralittoral environment is defined by two major seismic sequences (lower and upper), each one formed by internal seismic units. The sequences and units are characterised by downlapping surfaces made up of deposits formed by progradation of coastal lithosomes. The stratigraphy and stratal architecture, displaying a retrogradational arrangement with progradational patterns of minor order, were controlled by different sea-level positions. The stratigraphic division represents the coastal response to the last fourth-order transgressive and highstand conditions, modulated by small-scale sea-level oscillations $(\approx 1-2 \mathrm{~m})$ of fith to sixth order. This study also highlights the advantage of an integrated analysis using acoustic/seismic methods for practical assessment of the anthropogenic effects on infralittoral domains based on the association of marine geological observations.
\end{abstract}

Keywords: infralittoral environment, morphology, stratigraphy, Holocene, El Masnou.

RESUMEN: El ambiente sedimentario infralitoral de El Masnou (provincia de Barcelona, Mediterráneo NO): MORFOLOGÍA y ESTRATIGRAFíA Sísmica del Holoceno. - En este trabajo se presenta el estudio detallado de la morfología y la estratigrafía sísmica y secuencial del Holoceno que caracteriza al ambiente infralitoral de El Masnou y que ha sido llevado a cabo mediante datos obtenidos con sonda multihaz y perfiles de sísmica monocanal de alta resolución de GeoPulse. Este ambiente infralitoral se extiende hasta los 26-30 m de profundidad y está morfológicamente caracterizado por dos cuñas deposicionales cuyas superficies están afectadas por surcos erosivos, deslizamientos, campos de ondas de sedimento de pequeña y gran escala, y formas de origen antrópico (fosas y hoyos de dragado). También se identifican terrazas erosivas en el área de transición a la plataforma continental. La estratigrafía del Holoceno de este ambiente infralitoral está definida por dos secuencias sísmicas (inferior y superior), y cada una de ellas comprende internamente unidades sísmicas. El desarrollo de esta estratigrafía y de su arquitectura ha estado controlado por cambios del nivel del mar. Las divisiones estratigráficas definidas representan la respuesta costera al último estadio transgresivo y de alto nivel del mar de $4^{\circ}$ orden, modulado por pequeñas oscilaciones $(\approx 1-2 \mathrm{~m})$ de nivel del mar de $5^{\circ}$ y $6^{\circ}$ orden. Por otra parte, el presente estudio muestra las ventajas que ofrecen las disciplinas de geomorfología y estratigrafía sísmica y secuencial, así como el uso de técnicas acústicas/sísmicas, para efectuar valoraciones prácticas sobre los efectos antropogénicos en el medio infralitoral, en base a observaciones geológicas marinas.

Palabras clave: ambiente infralitoral, morfología, estratigrafía, Holoceno, El Masnou. 


\section{INTRODUCTION}

During the last two decades, a great deal of research has focussed on the morphology and sedimentology of coastal environments, which are of vital interest for coastal management and are important for the long-term stability of coastal communities, economic activities and amenities (Trincardi and Syvitski, 2005). This is particularly true in Spain, where the whole Mediterranean coast has been affected by tourism and industry during the last 40 years.

Previous research on coastal deposits has dealt mostly with the coastal evolution of supralittoral and interlittoral environments because they are the ones most affected by human activities. Studies of infralittoral environments, mainly those dealing with deposits making up the infralittoral wedges (Medialdea et al., 1989) or infralittoral prograding wedges (Hernández-Molina et al., 2000), have focused mainly on their connection with the continental shelf and have mainly addressed sedimentary processes. In recent years there has been increasing interest in infralittoral environment studies aimed at improving knowledge of aspects that may be important for the future of coastal communities, such as the exploitation of offshore resources, corridors for communication and transport, fishing habitat protection, preservation of wetlands, and protection of coastal communities from natural and anthropogenic hazards.

The present study was carried out in the framework of the European BeachMed-e project (INTERRREG Programme), whose main objective was to characterise and improve technical and administrative instruments for strategic management of coastal defence, and for a sustainable development of Mediterranean coastal zones. A special target of this objective is to study coastal vulnerability to infrastructure affecting sediment transport along coastline, such as ports, piers, dams, breakwaters and artificial reefs (http://www.beachmed-e.it). The present study was carried out in the framework of this target, in order to assess the vulnerability of the El Masnou marina (NW Spain) (Fig. 1A). This infrastructure affects the longshore current, leading to two undesired effects on the El Masnou coast: i) sediment accumulation off the breakwater of the marina, resulting in infilling that blocks the entrance to the harbour, and ii) erosion of the coast in the neighbouring areas, with the resulting loss of beaches for tourist amenities. These effects have led local, regional and national authorities to carry out dredging operations in the area to unblock the harbour and to nourish the El Masnou beach. A geological study of the infralittoral environment of the El Masnou coast was carried out in order to obtain a general knowledge of the sedimentary environment, the natural processes and the factors that have controlled sediment transport and deposition at the site of the marina. The study area comprises $10 \mathrm{~km}$ of the El Masnou coastline, between the El Masnou marina and a similar structure: the Premia de Mar marina located to the north. This stretch of coastline is located in the Maresme coastal region, which is about $47 \mathrm{~km}$ long (Fig. 1A). It has about $79 \%$ of beaches, and is highly disturbed by anthropogenic factors such as buildings, the 6 marinas and the national railway built in the supralittoral environment during the late 19th century.

The present article defines and characterises the Holocene sedimentary infralittoral environment of the El Masnou area $\left(29 \mathrm{~km}^{2}\right.$ in size $)$. The aims of this study were: a) to characterise the geomorphology in detail; b) to define the seismic stratigraphy; c) to apply the sequence stratigraphy model; and with the results obtained from these aims d) to characterise the depositional system and its sedimentary evolution. Additionally, we highlight the advantage of using different disciplines (geomorphology, seismic stratigraphy and sequence stratigraphy), and different indirect acoustic methods (multibeam and high-resolution seismic records) to understand how the infralittoral features are formed by processes acting at different scales and to establish and assess anthropogenic effects on the infralittoral sedimentary environment.

\section{Geological framework and oceanography}

The El Masnou coast is located in the northern Catalonia Sea, in the northwestern Mediterranean (Fig. 1A). The coastline displays a NE-SW trend, and has been structurally controlled by the Pyrenean fault complex since the Oligocene (Medialdea et al., 1989). The Pleistocene-Holocene continental shelf of the El Masnou region is made up the vertical stacking of downlapping regressive deposits whose building was governed by glacio-eustatic sea-level changes (Checa et al., 1988). In fact, the high-resolution seismic stratigraphy of northern Catalonia is mostly a response to asymmetric and high-frequency fourth-order sea-level falls (100-110 ky) (Farrán and Maldonado, 1990; Ercilla et al., 1994; Hernández- 
Molina et al., 1994; Ercilla et al. 1995; Chiocci et al., 1997). The local differences in stratal pattern, thickness, directions of progradation and distribution were conditioned by the interplay between local factors (e.g. subsidence, sediment sources and morphology) and small-amplitude fifth- to sixth-order sea-level fluctuations (Díaz and Ercilla, 1993; Ercilla et al., 1994; Ercilla et al., 1995; Ercilla and Alonso, 1996; Chiocci et al., 1997; Somoza et al., 1998). The nearsurface sequence stratigraphy of the shelf of the El Masnou region is thus characterised by the presence of large-scale transgressive sand bodies formed during the Holocene transgression, and their relative development and preservation seem to be controlled by the interplay of several factors, such as the punctuated nature of this transgression, the sediment supply, the circulation pattern, and the topography (Díaz and Maldonado, 1990).

El Masnou has a sandy, straight (slightly curvedconcave), wave-dominated coastline. The sand of this coast is mostly supplied by the Tordera River, located $43 \mathrm{~km}$ to the north (Sorribas, 1991) (Fig. 1A). The local sediment source comprises four short (2.5 km long), ephemeral streams (Monsolis, Alella, Teia and Premia) (Fig. 1B), which drain areas of a few hundred square kilometres, providing sediment to the El Masnou coastal lithosomes during short-lived flood events (mostly from October to December) and remaining dry the rest of the time. The Holocene littoral prism of this area displays a wedge-shaped geometry whose thickness decreases seaward to disappear at 20-30 m water depth. It is roughly parallel to the coastline and its boundary with the inner shelf is marked by a downslope change in slope gradients, from about $<4^{\circ}$ to $0.2^{\circ}$. This wedge is defined acoustically by discontinuous stratified and opaque facies, and sedimentologically by sands whose grain size decreases progressively seaward (Medialdea et al., 1989). Seismic and sequence stratigraphy of the deposits making up the Holocene littoral prism of Catalonia and other sectors of the Spanish coast, both Mediterranean and Atlantic, reveals that the outbuilding of this wedge has been intrinsically conditioned by sixth-order sea level fluctuations which have modulated the Holocene sea-level highstand (Hernandez-Molina et al., 2000). The imprint of the sea-level changes seems to be quite independent of the amount of sediment supply, subsidence/ uplifting and morphology. These local factors have conditioned the unequal distribution and preservation of the littoral prism, as well as its growth pat- tern (Lobo et al., 2001, 2002). The continental shelf of the El Masnou area has a mean width of $21 \mathrm{~km}$, and the shelf break is at $130 \pm 20 \mathrm{~m}$ (Fig. 1A). The shelf is affected by canyon heads, such as that of the Blanes Canyon to the north which enters a few kilometres into the shelf, affecting the local shelf currents and dispersal of sediments during the late Quaternary (Diaz and Maldonado, 1990) (Fig. 1A). The general seafloor topography of this shelf is the result of coastal erosion during the last transgression (the Versilian transgression), and the main feature is an E-W morphological step that produces a sharp change in the slope profile of the shelf (Checa et al.,1988; Medialdea et al., 1989; Díaz and Maldonado, 1990). The sediments on this shelf comprise an extensive sheet of sands and sandy muds deposited during the Versilian transgression, except in areas off river mouths, where muddy prodeltas developed during the last sea-level highstand (Checa et al., 1988; Medialdea et al., 1989).

With respect to the oceanography, the El Masnou coast has a microtidal range $(\approx 0.44 \mathrm{~m})$, based on tidal records from Barcelona harbour (Medialdea $e t$ al., 1989). The prevailing currents in the study area are controlled by the cyclonic eddy of the western Mediterranean derived from the Liguro-Provencal current (Millot, 1999). The coastal area is affected by a low-energy wave climate, with mean wave heights of $1 \mathrm{~m}$ and a mean period of about $4 \mathrm{~s}$ (Gracia et al., 1989). Specifically, for the last 11 years, the El Masnou coast has been exposed to swell waves from NE to $\mathrm{SW}$, the most predominant ones being those from the NE-E ( $\approx 45 \%$ of the time). Swell waves from the SW are also common $(\approx 17 \%$ of the time) and to a lesser extent ones from the SE and S (both $15 \%$ of the time). The annual mean significant wave height (Hs) is $0.7 \mathrm{~m}$. Storm conditions are recorded mainly from October to December. These events can reach an average maximum Hs close to $6 \mathrm{~m}$, with a maximum of up to $10 \mathrm{~m}$ (Cendrero et al, 2005; Nuez et al., 2008). The most important storms are those from the $\mathrm{E}$, which have a typical duration of few days and are often associated with the above cyclonic activity in the western Mediterranean (Ojeda and Guillén, 2006). The predominant littoral drift is toward the S-SW (Flos, 1985; Font et al., 1988; Medialdea et al., 1989). This drift is subject to the interference of marinas and breakwaters. As a result, sand accumulates updrift of the marinas, resulting in a negative balance downdrift (Durán et al., 2008; Nuez et al., 2008). In the El Masnou marina area, this is leading 


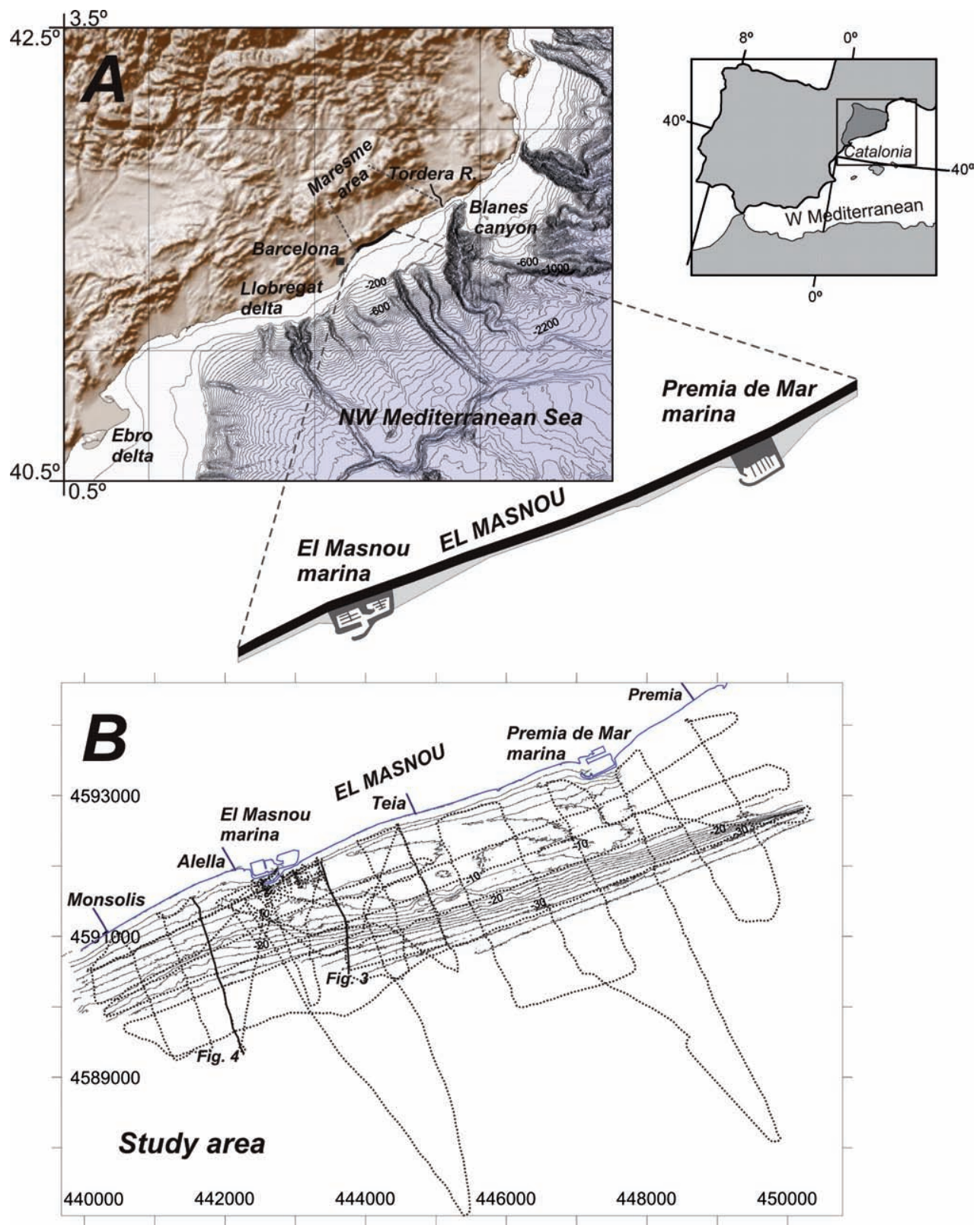

FIG. 1. - A. Map illustrating the location of the study area, the major river (Tordera River) supplying sand to the El Masnou Coast, to the north, and the main Tordera and Ebro delta systems to the south. The literature from these deltas was used for the interpretation of some of our results. Likewise, this map shows the general morphologic configuration of the continental margin with the main canyons affecting the physiography. B. Multibeam bathymetric map (in metres) and location of the GeoPulse seismic lines in the study area. Black lines refer to seismic lines in Figs. 3 and 4.

to the erosion of a long stretch of the coast and the accumulation of a significant volume of sand in the submarine areas surrounding the marina (Durán et al., 2008).

\section{MATERIALS AND METHODS}

This study was undertaken using multibeam echosounder and single-channel seismic profiles. Two multibeam bathymetric surveys were carried out, one in November 2006 and one in May 2007. The comparison between the bathymetric maps allowed the temporal variability of morphologic features to be monitored. A total of $136 \mathrm{~km}$ of high-resolution seismic reflection profiles were collected with a GeoPulse system (350 KJ) (Fig. 1B). These profiles vary in quality according to the sea conditions, but the major regional reflectors and stratal patterns can be correlated and recognised over most of the area.

The discontinuity surfaces plus the seismic facies were used to define the seismic sequences and 
units - the two hierarchies of depositional units that we used to define the stratigraphy of the infralittoral environment. The natures of the bounding reflectors, the reflector configuration and the architecture pattern were used to interpret the depositional events at two different scales: seismic sequences and units.

\section{RESULTS AND DISCUSSION}

\section{Morphology}

Five groups of morpho-sedimentary features are distinguished according to their origin (Fig. 2). Four of them represent sedimentary features: depositional, erosive, instability and hydrodynamic features. The fifth one is an anthropogenic feature. The depositional features are the largest ones (tens of $\mathrm{km}$ ) and their seafloor is affected by the remaining features, which are of minor scale (tens and hundreds of metres, and kilometres).

The depositional features comprise infralittoral wedges that are identified along the El Masnou coast (Fig. 2); they are shore-parallel and seaward prograding bodies that extend from the distal edge of the shoreface (Medialdea et al., 1989). At least two superimposed wedges extending down to different water depths are found. The relative age of these two wedges was established based on seismic records and the geometry of the bathymetric lines, which reflect abrupt changes in the regional slope profile defining scarps on the seafloor (Figs. 2, 3

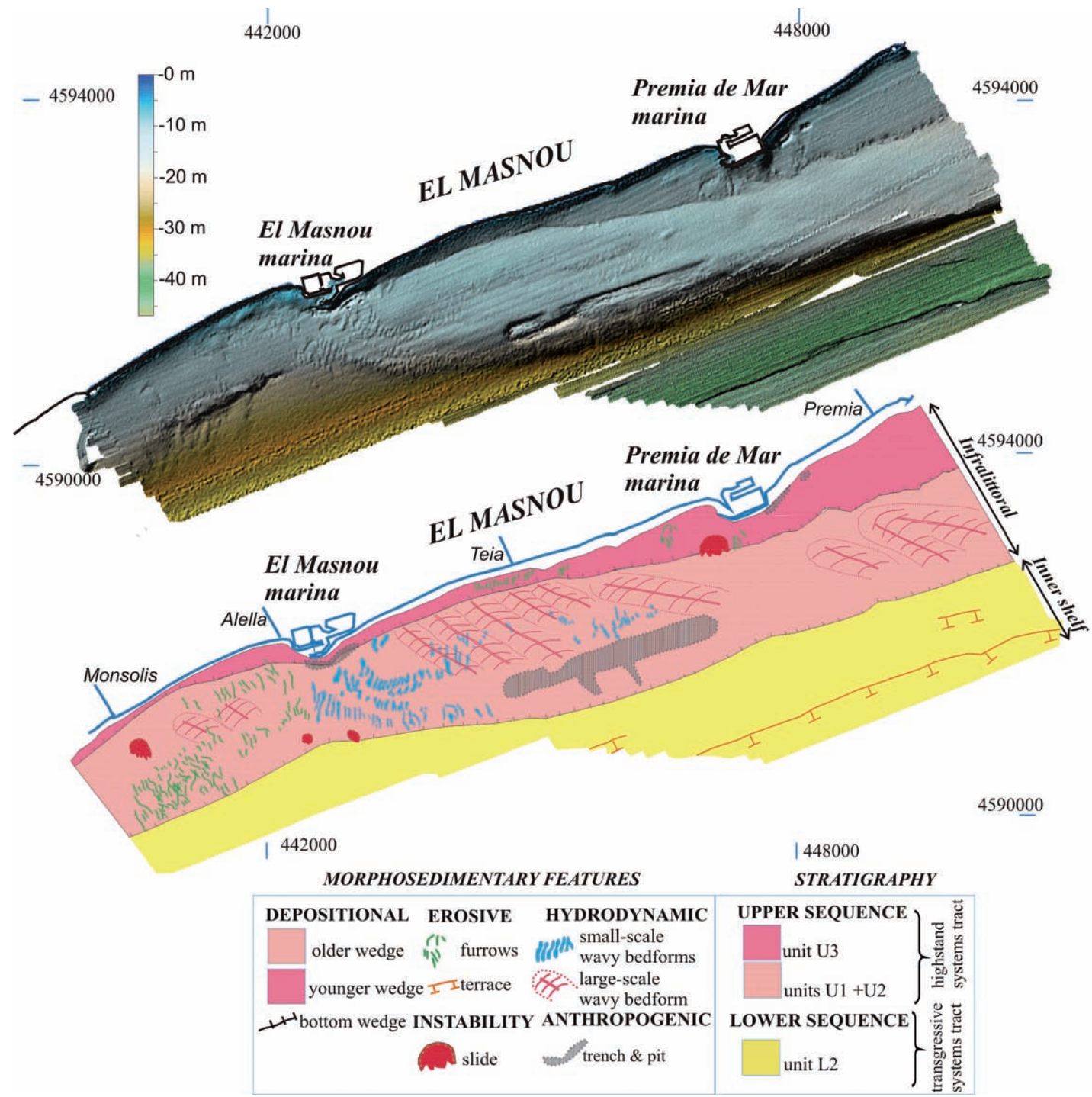

FIG. 2. - Multibeam shaded mean depth obtained in November 2006 (top) and line drawing (bottom) maps illustrating the main morphosedimentary features identified in the El Masnou infralittoral environment. Map illumination from NW. The line drawing map also shows the seafloor distribution of sediments forming the seismic sequence and units. 
$184 \cdot$ G. ERCILLA et al.

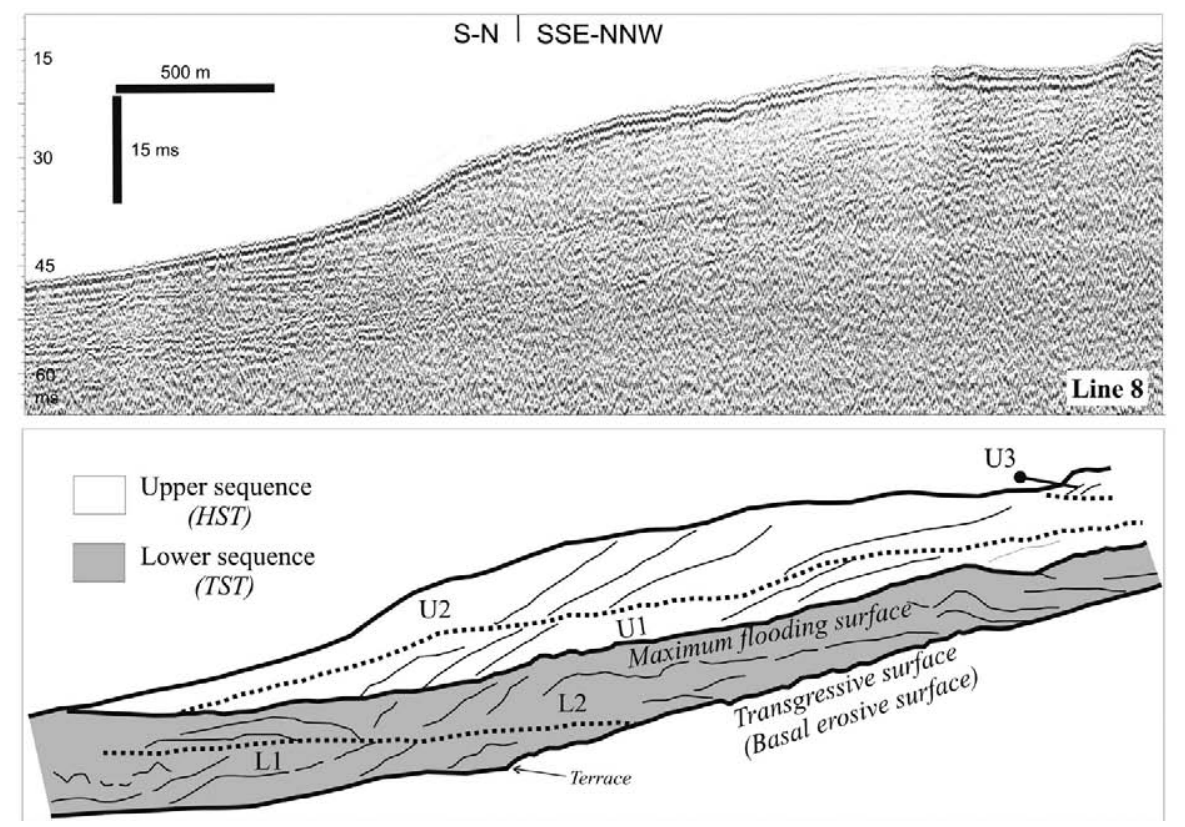

FIG. 3. - High-resolution seismic profiles and line drawing (GeoPulse, $350 \mathrm{~kJ}$ ), illustrating the seismic and sequence stratigraphy defined in the El Masnou infralittoral environment. The lower seismic sequence, in grey, represents the last fourth-order transgressive system tract (TST), and the upper sequence, in white, the last fourth-order highstand system tract (HST). L1 and L2, and U1, U2 and U3 refer to seismic units defined within the lower and upper sequences respectively. Vertical scale is in milliseconds (ms), two-way travel time.
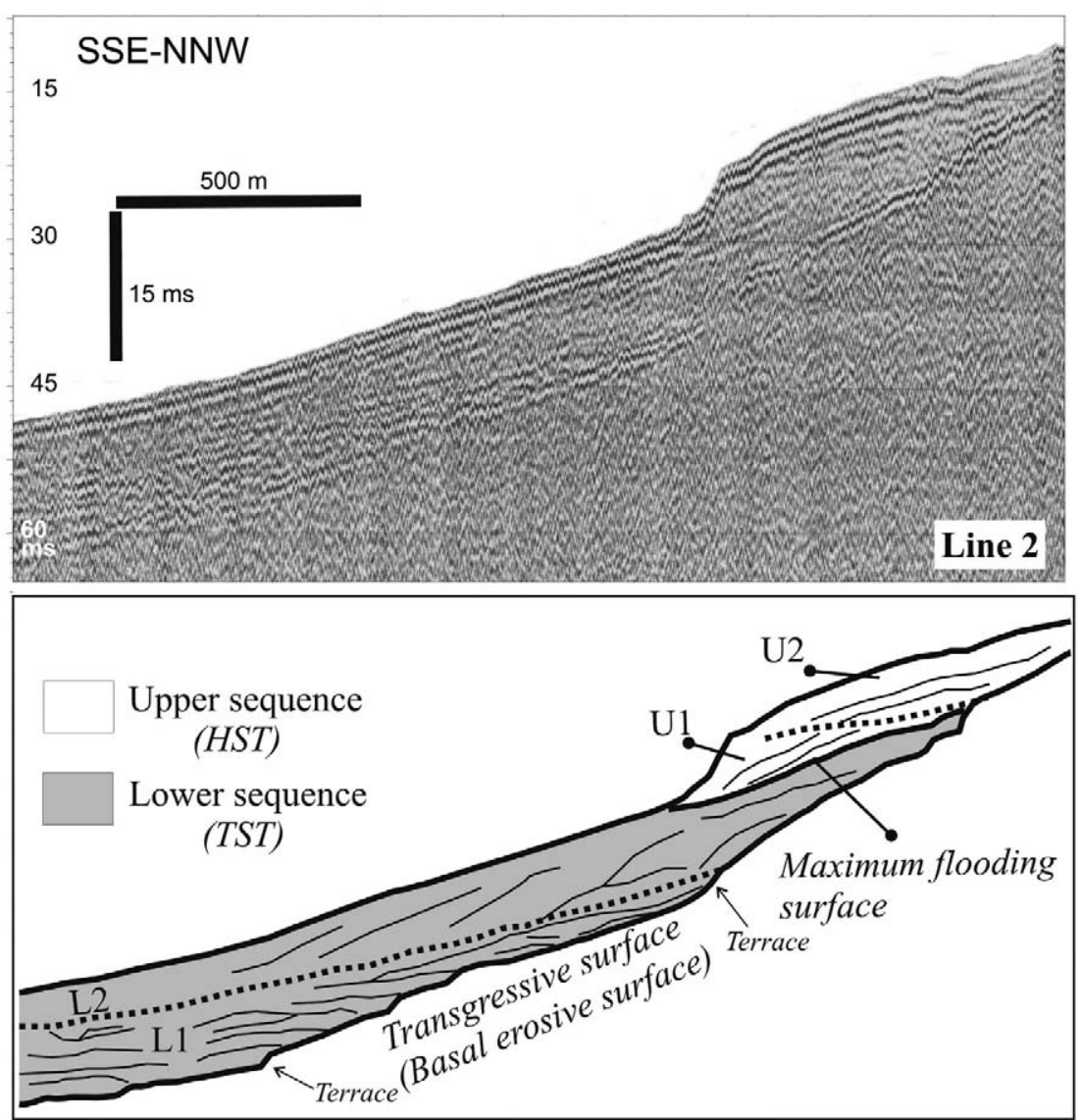

FIG. 4. - High-resolution seismic profiles and line drawing (GeoPulse, $350 \mathrm{~kJ}$ ), illustrating the seismic and sequence stratigraphy defined in the El Masnou infralittoral environment. The lower seismic sequence, in grey, represents the last fourth-order transgressive system tract (TST), and the upper sequence, in white, the last fourth-order highstand system tract (HST). L1 and L2, and U1, and U2 refer to seismic units defined within the lower and upper sequences, respectively. 
and 4), and also indicate that the wedges have become smaller and shallower over time. The lower or older infralittoral wedge extends down to 26-30 $\mathrm{m}$; the upper or recent one reaches water depths ranging from 7 to $15 \mathrm{~m}$. The older wedge shows a variable geometry to the north and south off the El Masnou marina. To the north, it displays a sigmoidal geometry with slope gradients of $<0.5^{\circ}$ that increase sharply to $3^{\circ}$ in the distalmost areas. The gentle areas define a seafloor whose regional slope trends northeast. To the south, the geometry of the older wedge is oblique, with gradients of about $1^{\circ}$ that increase at its most distal end to about $2^{\circ}$. This geometric change from sigmoidal to oblique is also well reflected by the bathymetric lines, which are seaward-convex to the north and seaward-concave to the south. The younger infralittoral wedge displays an oblique geometry with slope gradients that vary between $1^{\circ}$ and $3^{\circ}$.

The erosive features include furrows and terraces (Fig. 2). The furrows comprise groups of negative irregular lineations tens and hundreds of metres in length and roughly perpendicular to the slope. They define an irregular seafloor in at least eight areas of variable dimensions (from about $1.2 \mathrm{~km}^{2}$ to hundreds of $\mathrm{m}^{2}$ ). They mostly appear in the proximal areas, down to $10 \mathrm{~m}$ water depth, affecting the seafloor of the youngest infralittoral wedge, although one group is also identified between 14 and $26 \mathrm{~m}$ water depth, affecting the older infralittoral wedge. All of them occur in areas of seafloor with relatively high steep gradients (between $2^{\circ}$ and $5^{\circ}$ ).

The terraces define striking scarps of metric relief with the steep side oriented seaward (Fig. 2). At least three terraces up to $6 \mathrm{~km}$ long parallel to the bathymetric lines are identified at different water depths of between 30 and $40 \mathrm{~m}$, all of them seaward of the older depositional wedge, where the transition to the inner continental shelf occurs.

The instability features are characterised by slides that are easily recognizable on the surface by their headscarp and the slide sediment resting at their base (Fig. 2). The headscarp displays an arcade shape 125 to $325 \mathrm{~m}$ wide in plan view; the slide sediment displays a homogenous seafloor and has a short runout distance, suggesting a lack, or only a few degrees, of deformation. Four slides were mapped affecting the nearsurface of the infralittoral wedges, where slope gradients are about $1^{\circ}$.

The hydrodynamic features are fields of largeand small-scale wavy bedforms (Fig. 2). These are considered features that are the product of the incident waves, especially storm wave currents. The larger-scale wavy bedforms comprise a series of at least 11 large ridges (hundreds of metres long), with distances between them of up to $600 \mathrm{~m}$, and metric reliefs. They develop on the gentler seafloor $\left(<0.5^{\circ}\right)$ of the proximal part of the older infralittoral wedge. These ridges display a WNW-ESE and NW-SE trend and are oblique with respect to the regional slope.

The small-scale wavy bedforms are characterised by sinuous- and straight-ridge features (tens of metres long), and some display bifurcations. The ridges are wider than the troughs between them. They are roughly oblique to perpendicular to the slope, display mostly a NNE-SSW and NE-SW trend, and develop at the older infralittoral wedge. They are located at variable water depths (mainly between 15 and $30 \mathrm{~m}$ ) with different slope gradients, and display different degrees of freshness. The best-defined bedforms with rectilinear linear ridges and troughs are located in the sector with the steepest gradients $\left(5^{\circ}\right)$, whereas on gentler slopes the bedforms are smoother, have sinuous ridges and troughs, and/or are less enhanced. The two multibeam bathymetries obtained in the study area in 2006 and 2007 indicate that the smallscale wavy bedforms located at shallower water depths off the El Masnou breakwater have changed their shape; specifically, their plan-view shape and outlines were less enhanced in November 2006 than in May 2007 (Fig. 3). In November 2006, the trace of the small-scale wavy bedform outlines was discontinuous because they had been reworked and/or subdued (Durán et al., 2007).

The anthropogenic features result from the reworking of the seabed by successive dredging to nourish the eroded El Masnou beach and to avoid the infilling of the El Masnou marina entrance. These features comprise trenches and pits (Figs. 2 and 5). The trenches are located at different water depths, the largest one $(2.5 \mathrm{~km}$ long and $<4 \mathrm{~m}$ depth) in the steeper area of the older depositional wedge, and the shortest one $(800 \mathrm{~m}$ long and $<4$ $\mathrm{m}$ depth) paralleling the El Masnou breakwater. The pits are subcircular with $1.5-3 \mathrm{~m}$ depth and a diameter of about $17-23 \mathrm{~m}$. They surround the submarine areas of the breakwater. The comparison between the two multibeam bathymetries shows that the trenches and pits have been partially filled by sands transported by the longshore transport (Durán et al., 2007, 2008). 


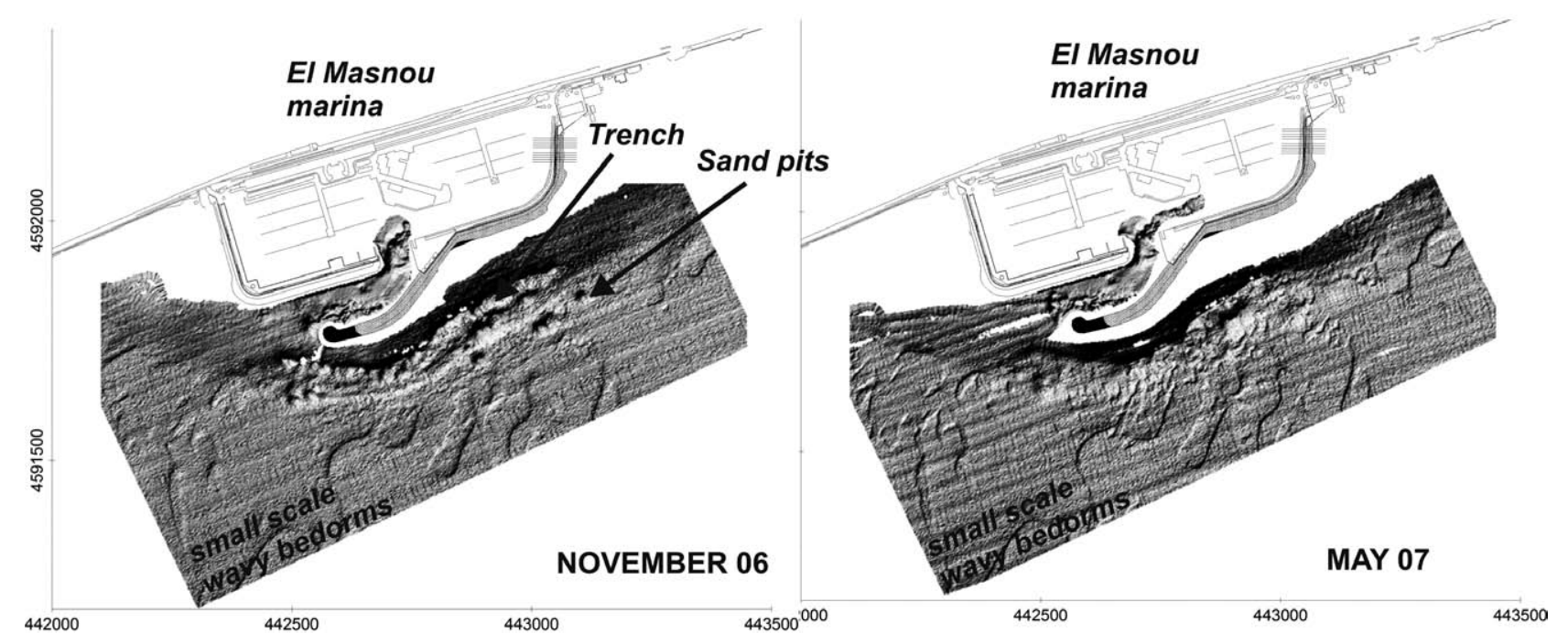

FIG. 5. - Multibeam shaded mean depth maps obtained in 2006 and 2007, illustrating the dragging trench and pits, and the small-scale bedforms off the El Masnou breakwater. Note how these features have modified their morphology. Map illumination from NW.

\section{Seismic stratigraphy}

The high-resolution seismic stratigraphy analysis of the El Masnou infralittoral environment comprises two major seismic sequences, the lower (L) and upper (U) sequences, each one formed by internal units (Figs. 3 and 4). These sequences are backstepping onto an erosive surface (hereinafter the basal erosive surface) that is regionally traceable throughout the continental shelf (Medialdea et al., 1986, 1989). Under this surface the acoustic basement is defined. The basal erosive surface is irregular and locally dis-
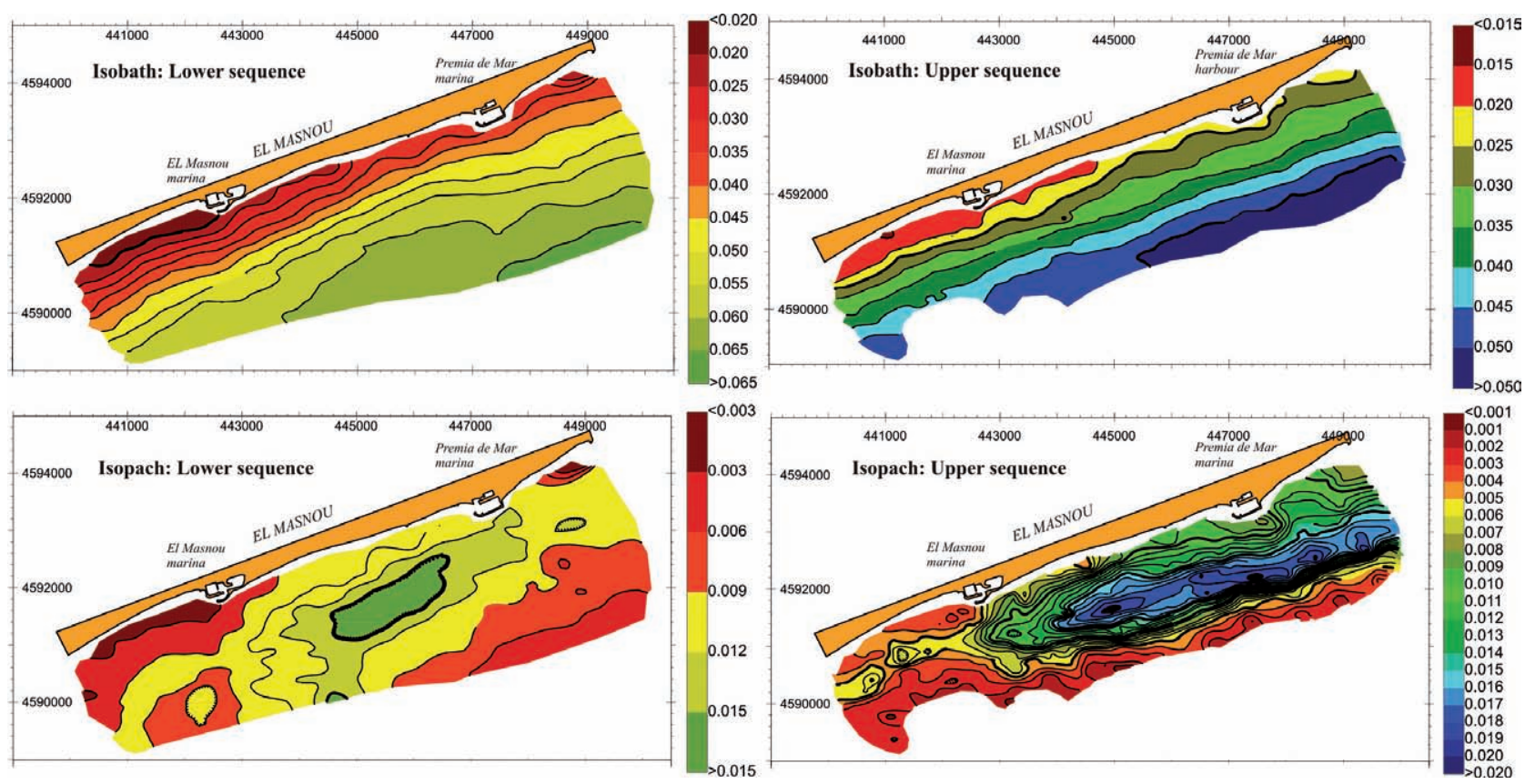

plays terraces of metric relief, with the steepest side oriented seaward. Its paleotopography reflects a surface sloping seaward with a gradient that increases laterally toward the SW. The thickness of both sequences varies between 20 and $>65$ milliseconds.

The lower seismic sequence comprises two subtabular units (L1 and L2, from older to younger) separated by a discontinuity surface that onlaps onto the above-mentioned regional erosive surface at about 20-35 m water depth (Figs. 3 and 4). The isopach map of this sequence shows a thickness varying between $<3 \mathrm{~ms}$ and $15 \mathrm{~ms}$ (Fig. 6). The distribution

FIG. 6. - Isobath and isopach maps of the Lower and Upper Sequences. Vertical scale in seconds. 
of these values indicates that thickness increases seaward and then decreases again, reflecting a major elongated depocentre of $0.15 \mathrm{~ms}$ between the Premia de Mar and El Masnou marinas. Locally, a minor depocentre of $12 \mathrm{~ms}$ occurs at the south of the El Masnou marina.

The lower boundary of L1 and L2 is a discontinuity surface defined by an onlap surface toward the coast that evolves seaward to a downlap surface (Figs. 3 and 7). The upper boundary seems to be an irregular erosive surface, and that of the L2 unit represents the seafloor surface seaward from a water depth of 26-30 m (Figs. 3 and 4). The paleotopography of this surface is similar to the basal erosive surface, sloping seaward and steeper toward the SW (Fig. 6). Internally, both units are formed by clinoforms with oblique progradational and backstepping aggrading configurations, and also by amalgamated concave reflectors. The distal ends of both units extend toward the inner shelf, far from the limits of the study area. The vertical stacking of both units lends a retrogradational or backstepping pattern to the lower sequence (Figs. 3, 4 and 7).
The upper seismic sequence rests unconformably over the lower sequence and the basal erosive surface in the most proximal areas (Figs. 3, 4 and 7). The isopach map of this sequence shows that the thickness increases seaward and then decreases again, and reflects a major depocentre of $0.20 \mathrm{~ms}$. This depocentre displays an elongated trend resembling the main trend of the older infralittoral wedge. Two small and aligned depocentres ( $7 \mathrm{~ms}$ thick) are locally identified to the south of the El Masnou marina (Fig. 6).

The upper sequence comprises at least three units, U1, U2 and U3, from older to younger (Figs. 3,4 and 7). These units parallel the coast and display a wedge-shaped geometry internally defined by seaward downlapping clinoforms. They differ in development and distribution. Units U1 and U2 are traceable throughout the study area, extending down to a water depth of 26-30 m. Unit U3 is smaller and thinner, being better developed to the north, where it extends down to $15 \mathrm{~m}$, than to the south, where it extends down to $7 \mathrm{~m}$. The vertical stacking of U1 to U3 deposits shows a retrogradational pattern. These

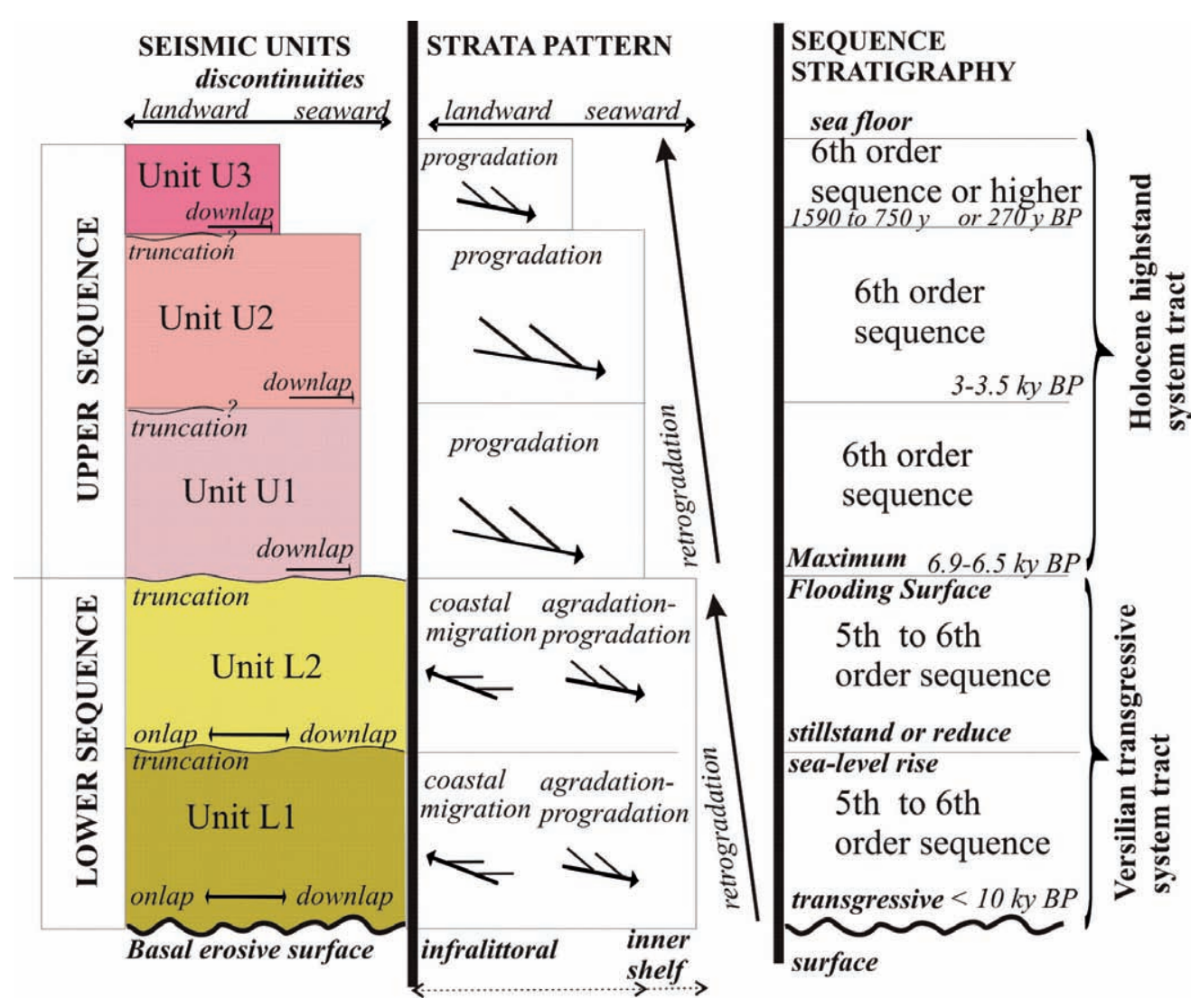

FIG. 7. - Schematic diagram showing type of boundaries, strata pattern and sequence stratigraphy age model of the stratigraphy defined in the El Masnou infralittoral environment. 
units make up the depositional wedges defined in the morphology: units $\mathrm{U} 1$ and $\mathrm{U} 2$ build the oldest wedge and unit U3 the youngest one (Fig. 2).

Units U1 and U2 were studied in detail (Figs. 3, 4 and 7). Their lower boundary is a downlap surface and their upper boundary seems to be an erosive and/ or toplap surface that is well displayed and outlined between the two units due to its angular pattern. Internally, they are defined by seaward prograding reflectors. The direction of progradation is normal to the coastline, although a progradation toward the $\mathrm{SW}$ is also defined in front of the El Masnou marina. This fact and the unequal development of this unit to the north (20 ms thick) and to the south (5 ms thick) of the El Masnou marina, suggest that the lateral coalescence of their prograding deposits occurred during its development (Fig. 6).

With respect to U3, only the most distal part of the wedge was surveyed. This part is characterised by a seaward downlapping pattern and has a thickness of about 9 ms (Fig. 3).

\section{Sequence stratigraphy and age model}

The seismic facies, discontinuities, internal pattern and stratigraphic architecture defined by the lower and upper sequences and their respective units indicate that development of the El Masnou stratigraphy and stacking patterns have been governed by the Holocene large- and small-amplitude, highfrequency sea-level changes. With the absence of dating, the correlations of the El Masnou sequence and units with sea-level changes are based on a theoretical correlation with data from the literature, especially that which deals with areas close to the study area and around the Iberian Peninsula. Somoza et al. (1998) defined a high-resolution seismic and sequence stratigraphy in the Ebro delta and adjacent coast for the Holocene, proposing a relative mean sea-level curve for this period. This curve was also used by Fernández-Salas et al. (2003) in the south of the Iberian Peninsula. Figure 8 illustrates the correlations between our stratigraphy and these other stratigraphies and the relative sea-level curve.

The basal erosive surface underlying the lower and upper seismic sequences represents the transgressive surface developed during the last fourth- order Versilian transgression (18000 to ca. 6900-6500 y BP; Díaz and Maldonado, 1990; Ercilla et al., 1995; Hernández-Molina et al., 2000), and in the study area it would have developed during its last stages (Figs.
3, 4 and 7). The onlapping seismic facies and backstepping stratal pattern that characterises the lower sequence indicate that it is formed by transgressive sediments deposited during this transgression. Therefore, the lower sequence is a transgressive system tract (TST) and its upper boundary represents the maximum flooding surface, the sea level being about 1-2 m above the present (e.g., Chappell et al., 1983; Marqués and Juliá, 1983, 1986; Gàmez, 2007) (Figs. 3, 4 and 7). Recent studies in the coastal environment of Spain indicate that this surface formed about 6800 y BP (Somoza et al., 1998; Fernández-Salas, 2008) (Fig. 8). The two seismic units, L1 and L2, which define the internal structure of this sequence, must be related to a smaller-amplitude and higherfrequency sea-level change that produced stillstand or reduced sea-level rise in the transgressive segment of minor order. Recent studies in the Spanish Mediterranean shelves suggest that formation of transgressive units has been governed by sudden and short-lived eustatic-climatic oscillations (fifth to sixth order) that mostly favoured the occurrence of periods of reduced sea-level rise (from 1 to a few metres) (Somoza et al., 1998; Lobo et al., 2001, 2002; Fernández-Salas et al., 2003). Specifically, there was a fifth-order fluctuation that represented a short-amplitude eustatic sea-level fall and produced a deceleration in the fourth-order Versilian transgression (Larcombe et al., 1995). In the Ebro delta this fluctuation has been dated at $8300 \pm 300$ y BP (Somoza et al., 1988).

The seaward downlapping seismic facies, progradational growth pattern, wedge geometry and distribution of the deposits forming the upper seismic sequence indicate that it comprises sediments deposited during the last highstand (Figs. 2, 3 and 7). Therefore, the upper sequence forms a highstand system tract (HST). Its depositional hierarchy and stacking pattern could be related to the influence of sea-level changes of fifth to sixth order. In that time, climatic changes led to variations in sea-level of small-scale amplitude (a few metres), leading to the formation of discontinuities and then changes in the sediment transport and deposition of the prograding wedges (Warner and Stanley, 1995; Somoza et al., 1998; Baker and Haworth, 2000; Banerjee, 2000; Gàmez, 2007; FernándezSalas, 2008) (Fig. 8). These changes must have led to the formation of units U1 to U3. Taking into account the relative magnitude of units $\mathrm{U} 1$ to U3, we consider that units $\mathrm{U} 1$ and $\mathrm{U} 2$ could be related 


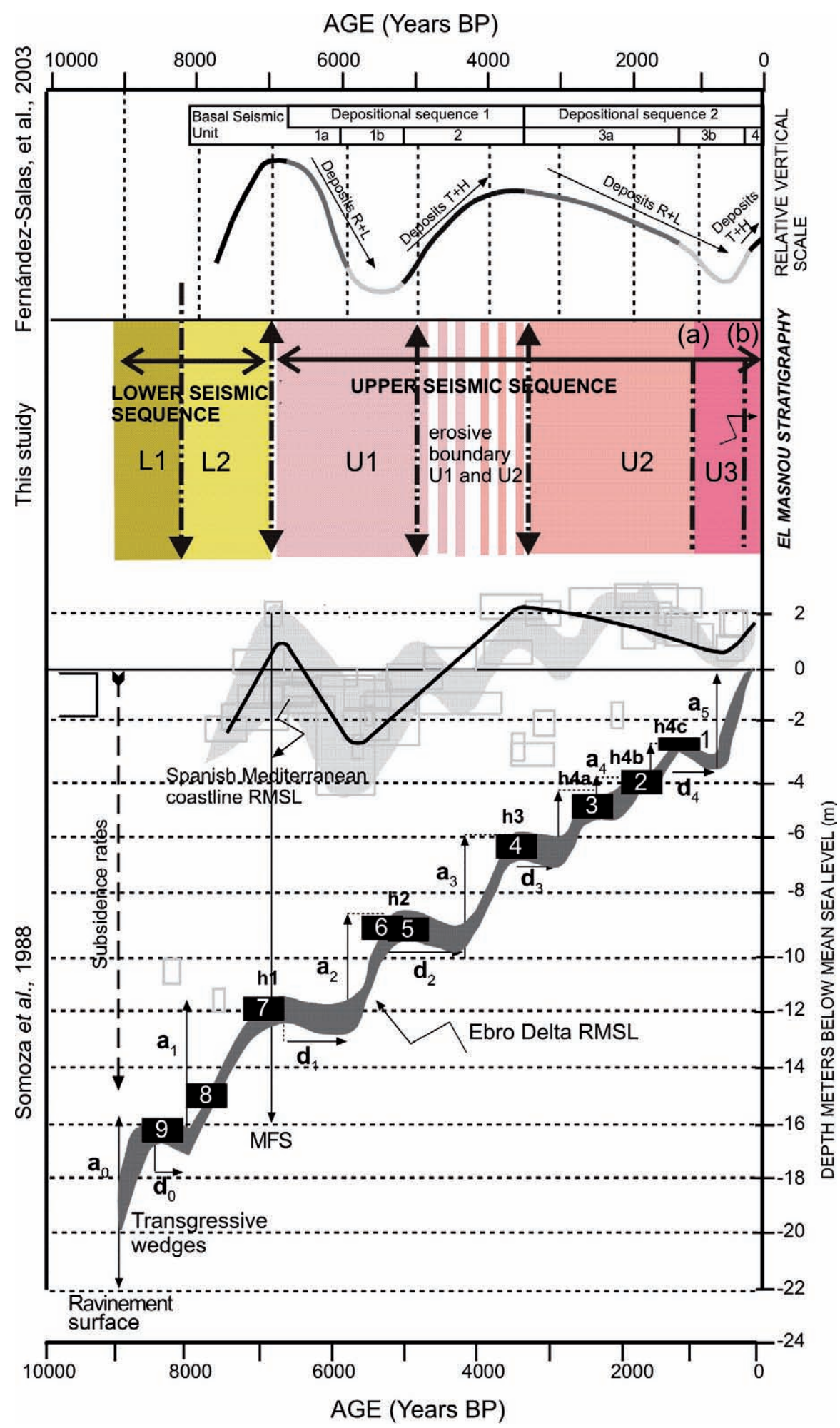

FIG. 8. - Theoretical correlations of our seismic and sequence stratigraphy with the stratigraphies and sea-level changes defined by Somoza et al. (1998) in the Ebro delta and by Fernández-Salas et al. (2003) in the south of the Iberian Peninsula. The comparative analysis indicates that units L1 and L2 would correspond to $\mathrm{d}_{0}$ and $\mathrm{a}_{1}$, respectively of Somoza et al. (1998), and the combination of the two units to the Basal Seismic Unit of Fernández-Salas et al. (2003). Unit U1 correlates with the combination of $\mathrm{d}_{1}, \mathrm{a}_{2}, \mathrm{~d}_{2}$ and $\mathrm{a}_{3}$ of Somoza et al. (1998) and seismic unit 1 within depositional sequence 1 of Fernández-Salas et al. (2003). The boundary between units U1 and U2 coincides with the eustatic maximum $\mathrm{h}_{3}$ described by Somoza et al. (1998). Unit U2 correlates with units $\mathrm{d}_{3}$, $\mathrm{a}_{4}$ and $\mathrm{d}_{4}$ of Somoza et al. (1998) and with seismic unit 3 within depositional sequence 2 of Fernández-Salas et al. (2003). Based on the two given interpretations about its millennial or centennial scale, unit U3 may correlate respectively with the combination of units $d_{4}$ and $a_{5}$ of Somoza et al. (1998) or only with $a_{5}$; likewise, it may correlate with subunit 3b (millennial scale) or seismic unit 4 (centennial scale) within depositional sequence 2 of Fernández-Salas et al. (2003). 
to the two major Holocene progradational phases reported in the Iberian coastal deposits, and also around the world (Van Andel and Laborel 1964; Donoghue, 1993; Hernández-Molina et al., 1994; Zazo et al., 1994; Goy et al, 1996; Somoza et al., 1998; Fernández-Salas et al., 2003). The occurrence of these phases was governed by sixth-order eustatic-climatic changes, and their exact time varies according to the region investigated (FernándezSalas, 2008). In the Iberian areas of the Atlantic Ocean and Mediterranean Sea, the first cycle occurred from $c a$. 6900-6500 y BP to 3000-3500 y $\mathrm{BP}$, and from 3000-3500 y BP to the present (Zazo et al., 1994; 1996; Fernández-Salas et al., 2003). We consider that unit U1 was built during this first progradation period, and U2 during the second one. This progradation has also been detected in deltaic sequences in southern areas close to the El Masnou area, specifically in the Llobregat delta (Gàmez, 2007) and the Ebro delta (Somoza et al., 1998). Between the two phases, there was a period of no progradation that could be associated with a generalised transgression event documented in some areas (Donoghue, 1993; Pascual et al., 1998; Somoza et al., 1998; Goy et al., 2003). We consider that this event could have favoured a gap or lack of progradation that imposed its signature on the El Masnou coastal sedimentation, forming the discontinuity surface between units U1 and U2.

Unit U3 has a different scale of magnitude to units U1 and U2 (Figs. 2, 3 and 4). It is smaller and thinner, and also has a different plane-view geometry and development along the El Masnou coast. It is better developed to the north, where it extends down to $15 \mathrm{~m}$, than to the south, where it extends down to $7 \mathrm{~m}$. Taking into account these considerations, we tentatively propose two interpretations. The first interpretation is that U3 could be a subunit of U2, and its formation could be related to the Medieval Warm Period-Little Ice Age Oscillation. The second interpretation is that it is probably of centenarian scale, and is related to the transgressive and highstand periods that have occurred since 270 yr ago and/or to a more local controlling factor in its development, such as the topography, wave regime or stream regimes. The literature (e.g., Zazo et al., 1996; Somoza et al., 1998; Lobo et al., 2001, 2002; Fernández-Salas et al., 2003; Goy et al., 2003; Gàmez, 2007) indicates that all these local changes are the main factors controlling the supply of sediment to continental shelves, and also its dispersal; for example, in deltaic areas these changes have caused deltaic lobe switching

The theoretical correlation with other stratigraphic interpretations of the Iberian Peninsula indicates that fifth- and sixth-order sea-level changes have a similar sedimentary product at both sequence and unit scale (Fig. 8). Only the transgressive and/ or stillstand periods at unit scale are not seismically detected in our seismic records, whereas in other areas they appear as thinner aggradational units. This could be because sediment formed during these periods would be below the resolution of our seismic method.

\section{Morphogenetic significance}

The combination of morphology, seismic stratigraphy and seismic facies allows us to establish that the Holocene architectural geometry of the El Masnou infralittoral system is characterised by large-scale depositional elements (i.e. transgressive and highstand deposits or depositional wedges), and small-scale elements (i.e. erosive, instability and oceanographic elements) that affect the largescale ones.

The subtabular geometry of transgressive deposits is formed when the coastline migrates landward and the recently deposited infralittoral prograding wedge is eroded and recycled, being left as a subtabular sheet. Terrace features remain preserved only in those places where the erosive action of the coastal processes has been greatest and/or has acted longest (Medialdea et al., 1986; Díaz and Maldonado, 1990; Ercilla et al., 1995). Thus, the terraces mapped at a water depth of $30-40 \mathrm{~m}$ in the transition zone to the inner shelf and those of the Versilian transgressive surface in the infralittoral environment reflect ancient stillstand positions of the coastline during its landward migration (Fig. 9). Similar transgressive terraces have been mapped on the surrounding continental shelf (Medialdea et al., 1986; Díaz and Maldonado, 1990) and are subparallel to those identified in this work.

The well-preserved wedge geometry displayed by the highstand deposits indicates that they represent the modern (in geological terms) infralittoral sediments (Fig. 9). The different plan-view geometry of the older and younger wedges and the variable progradation and thickness of the older wedge may all be a function of (paleo) topography and coastline orientation with respect to storm-driven transport (along- 


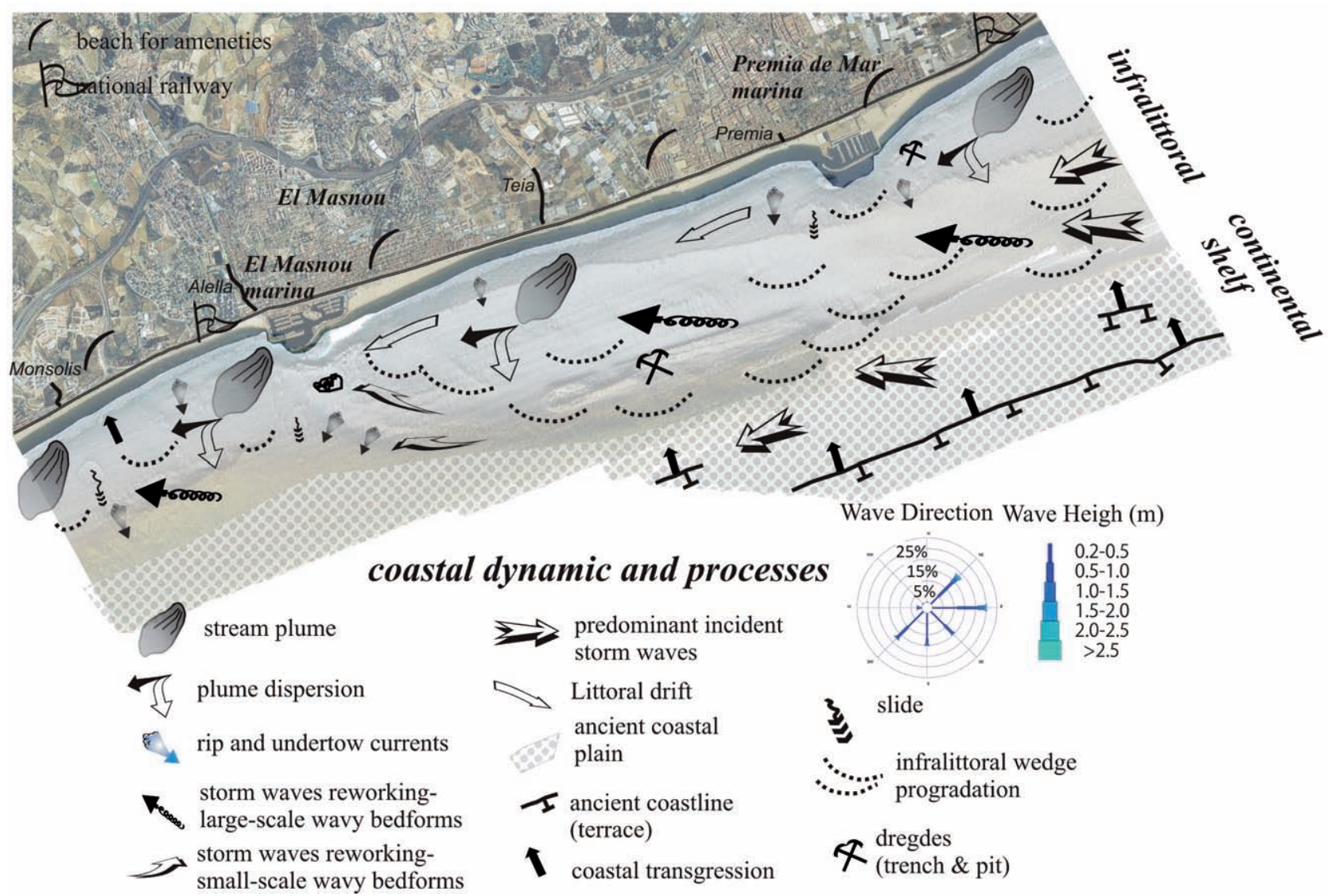

FIG. 9. - Sketch of the sedimentary processes that characterise the El Masnou infralittoral environment during the Holocene. This sketch is based on the morpho-sedimentary features and seismic stratigraphy. Anthropogenic features (buildings, national railway) on the subaerial coast are also displayed.

coast and alongshelf transports), or the interplay between them. This tentative interpretation is based on detailed studies carried out in ancient transgressive sand bodies and paleocoastlines in the neighbouring areas (Medialdea et al., 1986, 1989; Checa et al., 1988; Díaz and Maldonado, 1990). These studies allow us to consider several factors affecting the outbuilding and preservation of the recent wedges: i) general shelf topography, such as the presence of the Blanes canyon on the shelf to the north (Fig. 1A); ii) general (paleo)orientation of the coastline, such as a more westward orientation of the northern El Masnou (paleo)coast during the Versilian transgression, indicated by ancient infralittoral sand bars and terraces at different water depths on the continental shelf formed during that transgression (Medialdea et al., 1986, 1989; Díaz and Maldonado, 1990); and iii) the presence of small reliefs of the substratum. These factors and/or the interplay among them can modify the local flow fields and affect sediment dispersal and availability, leading to deposits that are unevenly deposited and/or preserved. More detailed regional morpho-dynamic studies are required in order to specify the transport and deposition patterns in the infralittoral environment.

The genesis of the rest of the morphologic features, such as the erosive, instability, hydrodynamic and anthropogenic features, are below the resolution of our seismic system, so their genetic characterisation is based on their location and morphologic characteristics (plan-view shape and dimensions) (Fig. 2). The genesis of the erosive features must be related to the scouring of rip and undertow currents, and/or hyperpycnal flows formed during storms and/ or flash stream floods, which are especially violent from September to November (Fig. 9). The irregular morphology of the furrows and their preferential distribution off and close to the streams suggest that their formation is related to the interplay of the two processes (Figs. 2 and 9). The huge sediment discharge during the flash floods favours the formation of hyperpycnal plumes that cross the infralittoral area, scouring the seafloor (Mulder et al., 1995; García et al., 2006; Fernández-Salas et al., 2007). 
As usual, the flash floods coincide with major sea storms, and the rip and undertow currents will affect the dispersal of the hyperpycnal flows and/or rework the recently formed furrows.

We do not have a clear explanation for the genesis of the slides and bedforms formed on the depositional wedges. Though the slides are similar in their plan-view geometry, their water depth and position on the wedges are different. The slope gradients are ruled out as a triggering mechanism because slides are absent where the gradients are steepest. In the infralittoral areas, the cyclic loading of the storm and internal waves could be considered as a triggering mechanism, but we have no arguments to explain the location of the slides. Further studies are required in order to determine their internal structure and the affected sediment.

With respect to the bedforms, we only know their plan-form geometry and in order to infer transport and flow directions it is essential to know their internal strata and migration patterns. Nevertheless, bearing in mind that the El Masnou littoral has a wavedominated coastline, we tentatively suggest that they are modern oblique bedforms probably formed by the incident waves, especially storm waves (Fig. 9). Our starting points for this suggestion are related to: the dominant hydrography, the results from the multibeam bathymetric monitoring and the bedform location. The hydrographical studies in the area indicate that the alongshelf and alongcoast transports are especially important when they are generated by storms coming from the NE-E (45\% of the time). The two bathymetries obtained in 2006 and 2007 show that only the small-scale wavy bedforms located at shallower water depths $(<10 \mathrm{~m})$ modified their plan-form geometry, being less enhanced in November 2006 than in May 2007; this fact suggests that these features were being reworked under the prevailing hydrodynamic conditions in 2006 and 2007. Both small- and large-scale wavy features kept their position at least at the bathymetric resolution scale (tens of centimetres), suggesting that either they are relicts or the storm waves occurring in 2006 and 2007 were too small to affect the entire seafloor of the infralittoral domain. The literature indicates the occurrence of huge NE-E storms during the last 18 years whose wave processes affected the seafloor down to a water depth of $>20 \mathrm{~m}$ (Sorribas, 1991), so we tentatively suggest that both types of bedforms could be modern. Based on the plan-view trend of the bedforms, the WNW-ESE and NW-SE large-scale undulations probably developed due to the NE incident storm wave currents. Also, based on the same directional criteria, the NNE-SSW and NE-SW small scale bedforms were probably formed by the E-NE incident storm wave currents (Fig. 9). However, in this case, the restricted location on the steeper face of the prograding wedge suggests that more factors should be taken into account (Fig. 2). When $\mathrm{E}$ and/or NE currents interact with seafloor topography they create local bottom currents that flow following the steeper face of the wedge. Moreover, these just-formed wavy bedforms could be reworked by rip and undertow currents and/or hyperpycnal flows, as is suggested by the more rectilinear shape and perpendicular trend displayed especially by the ones located where the wedge gradients are highest. However, more detailed studies that also include their internal structure are necessary to confirm their formation and whether they can be explained exclusively based on the present-day dynamics.

\section{Assessment of the anthropogenic effects}

The depositional regime can be defined as the prevailing conditions under which a sedimentary process occurs within a depositional system. These conditions are interpreted as a response to the geohistory of sea-level change, sediment input, hydrodynamic conditions, climate and basin subsidence (Swift and Thorne, 1991). The progressive human interventions and resource exploitation in coastal domains are well-known facts that are also affecting coastal depositional regimes and dynamics (Palanques and Guillén, 1995; Parrado Román et al., 1996; Muñoz Pérez et al., 1999; Gutiérrez Mas et al., 2003). In this context the main objective of this section is to assess the anthropogenic effects in the study area, where the geologic, climatic and hydrodynamic variables have also been analysed. This assessment will supply information about the vulnerability of the El Masnou infralittoral area to human actions.

The acoustic/seismic methods used in this study allowed us to assess the anthropogenic effects based on the association of geological observations. The morphological and stratigraphic observations in the study area comprise a wide range of time scales: millennial, centennial and yearly.

The present study indicates that human action related to dredging operations has a local impact on the modern El Masnou infralittoral sedimentary system. 

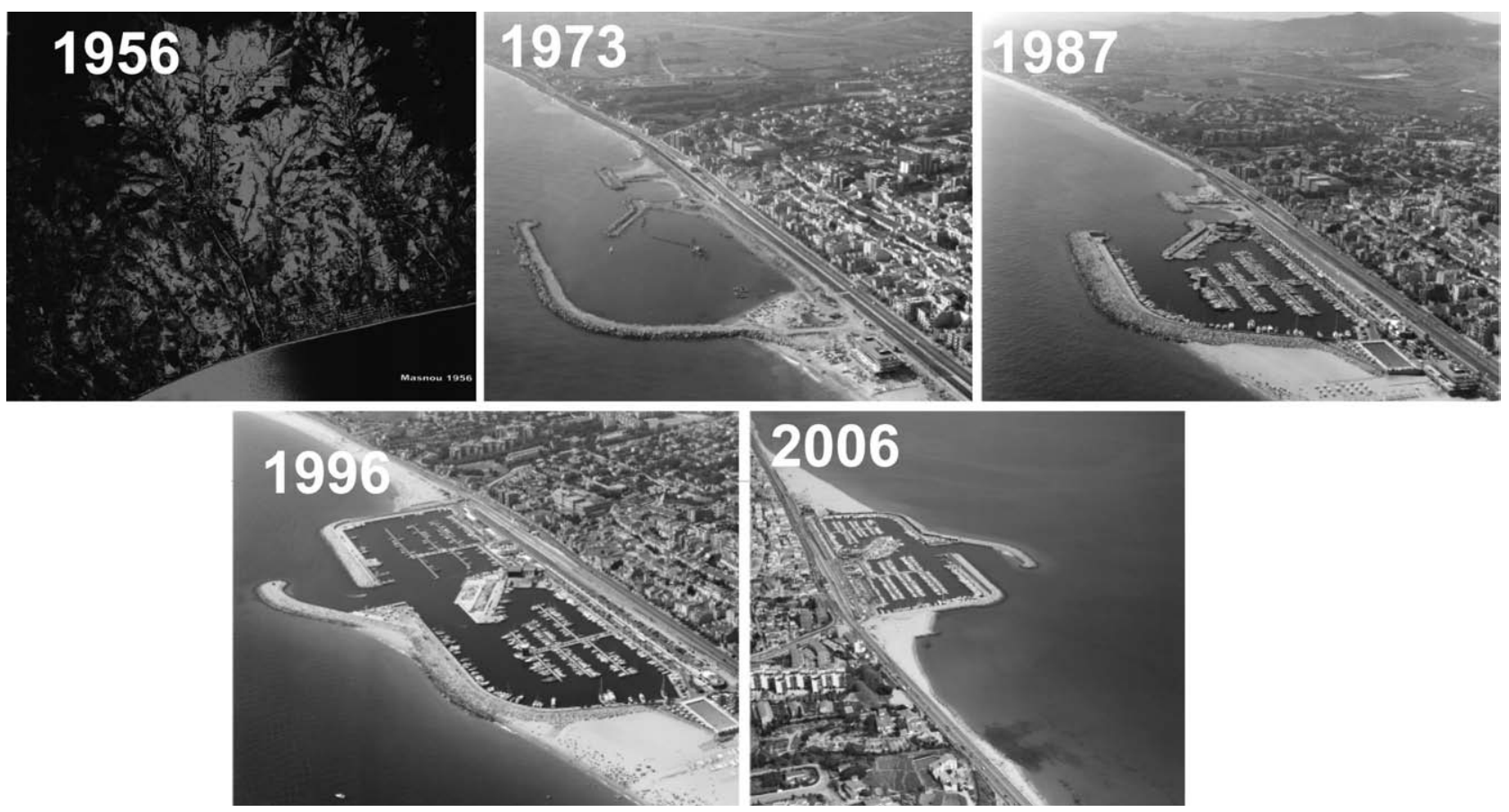

FIG. 10. - Temporal series of photos of the El Masnou marina. Construction of the marina began in 1973. The successive nourishment of El Masnou beach has allowed its progradation, mostly to the north of the marina, within a period of only 23 years (Durán et al., 2008), and has also led to an increase in the harbour infilling problems (Port Authorities, pers. comm). 1956 photo courtesy of the Spanish Air Force.

The mapped trenches and pits are related to different coastal management activities. The trenches were mainly created to nourish the beaches. The pits located off the El Masnou marina were mainly created in order to unblock and prevent the infilling of the harbour entrance, and the recovered sediment was also used occasionally to nourish the beach.

In the geological setting section, we mentioned that the coast of the El Masnou region is strongly disturbed by anthropogenic factors. Six marinas have been built since the 1960s, the national railway was built through the supralittoral environment in the 19th century, and many buildings have progressively occupied the hinterland coastal domain during the last thirty years. Moreover, submarine dredging operations have been carried out in the area since the 1980s, and tons of sand have been supplied to the beaches. Taking into account that the sediment sources of the study area are streams that work sporadically and the main fluvial source is the Tordera River located $43 \mathrm{~km}$ to the north (Fig. 1A), we expected these human actions to have had a greater impact on the infralittoral sedimentary system, which would have been detected with our acoustic/seismic methods. This is so because coastal dynamic studies based on acoustic and morphological methods in Spanish regions with a similar anthropogenic impact (Parrado Román et al., 1996; Muñoz Pérez et al., 1999; Gutiérrez Mas et al., 2003) indicate that alteration of the coastal systems is not only due to a decrease in river sediment supply, a rise in sea-level and an increase in the energy of marine dynamics, but also to the loss of drainage area in the supralittoral domain. This loss is caused by the buildings and engineering works that hinder the drainage and sediment supply, as well as by marine areas which affect the beach and nearshore processes and the evolution of the infralittoral environment.

In the El Masnou region the increase in buildings in the hinterland coastal domain and the construction of the railway and the marinas should have affected the stream sediment supply and particularly the sediment dispersal pattern both across and along the coast (Fig. 9). The buildings and the railway should have favoured the removal of sand from the beach and deposition in the infralittoral zone, mainly during storms, because the energy of the waves impinging on the coast is not dissipated in the supralittoral domain; the marinas should interrupt the longshore transport. The nourishment should represent an extra sandy sediment source to the infralittoral environment. However, the present morphologic and stratigraphic analyses suggest that the infralittoral environment studied does not reflect such an impact, or at least that it is negligible or below the resolution of our methods. 
The infilling problems of the El Masnou marina which tend to block its entrance and the loss of sand from the El Masnou beach every year, especially after the storms, suggest that the anthropogenic impact is affecting sediment dispersal in the supralittoral and interlittoral environments. In fact, the successive nourishment of this beach (Villares, 1999) has led to its progradation mainly to the north of the marina within a period of only 23 years (Durán et al., 2008) and to an increase in the harbour infilling problems (Port Authorities, pers. comm.) (Fig. 10).

The geological observations obtained in this work are explanatory because they help to understand the relationships between controlling factors, and can be translated to predictive models in coastal morphology and sedimentary dynamics. In fact, our results help to explain the sedimentation reaction when the infralittoral environment undergoes a climatic sealevel change, and are therefore of great interest for future predictions. Other high-resolution geological methods (monitoring of the seafloor with multibeam bathymetry, parametric seismic sources and long sediment cores) may be able to analyse the anthropogenic impact with more confidence. Nevertheless, the geological observations from this work can be translated to physical and computational models which have greater predictive capability, and together they may be used to assess the past and future anthropogenic impact with greater precision. The anthropogenic impact observed in this work refers to geological topics, but the biological/ecological and human points of view must also be taken into account. Dredging operations destroy benthic communities, and the erosion of the El Masnou beach and the infilling problems of the harbour affect the community amenities of the region and the tourist economy.

\section{CONCLUSIONS}

The Holocene deposits forming the El Masnou infralittoral environment constitute an infralittoral wedge or infralittoral prograding wedge, which develops between the supralittoral and the inner continental shelf environments (26/30 m water depth). The deposition of this wedge has been controlled especially by storm processes, mostly from the NE-E. The storm processes produce rip and undertow currents and hyperpycnal flows that transport the sediment in a seaward direction, and deposit it down to the storm base slope, a limit outlined by the base of the prograding foresets that marks the boundary with the inner shelf environment. These processes have controlled the seismic facies, stratal pattern and distribution on a seismic unit scale, and the morpho-stratigraphic architecture of the El Masnou infralittoral sedimentary system on a sequence scale. The different sequences and units defined in this environment indicate that the stratigraphy of the infralittoral wedge is made up of deposits formed by progradation of coastal lithosomes. However, its stratal architecture suggest that this progradation occurred during different sea-level positions, representing the coastal response to fourth-order transgressive and highstand conditions, modulated by small-scale sea level oscillations of higher frequency $\left(5^{\text {th }}\right.$ to $6^{\text {th }}$ order). In other words, the transgressive system tract represents ancient infralittoral prograding wedges, and the highstand system tract represents the modern infralittoral prograding wedge.

This sedimentary system is thus a combination of large depositional features influenced by sea-level changes upon which smaller erosive, instability, oceanographic and anthropogenic features are superimposed as a function of local wave regime, storm waves and resulting longshore and across-shore currents, sediment supply, coastal configuration and human actions. The large depositional prograding wedges operate on a millennial scale, whereas the smaller features are influenced by processes of variable and shorter time, at least yearly confirmed by this study. These processes help to rework, redistribute and configure the infralittoral seafloor sediments, thus giving the El Masnou infralittoral sedimentary system an identity of its own.

\section{ACKNOWLEDGEMENTS}

The work was supported by the European BEACHMED-e project, which is an INTERREG IIIC Regional Framework Operation (RFO), and by the Generalitat de Catalunya. Authors acknowledge to the authorities of the El Masnou harbour (F. Mestre and E. Barrenechea) for their helpful comments. Also, we thank to IEO in Málaga for allowing us to use the GeoPulse system. This work is in the framework of the The UNESCO International Project IGCP $n^{\circ}$ 396. G. Ercilla thanks to J. Llado for her 
personal permanent support and help in collecting local historical data. Two anonymous reviewers are thanked for helpfuld detailed comments.

\section{REFERENCES}

Baker, R.G.V. and R.J. Haworth. - 2000. Smooth or oscillating late Holocene sea-level curve? Evidence from cross-regional statistical regressions of fixed biological indicators. Mar. Geol., 163: 353-365.

Banerjee, P.K. - 2000. Holocene and late Pleistocene relative sea level fluctuations along the east coast of India. Mar. Geol., 167: 243-260.

Cendrero, A., A. Sánchez-Arcilla and C. Zazo.-2005. Impactos sobre la costa. Impactos sobre las zonas costeras. In: J.M. Moreno (ed.), Evaluación preliminar de los impactos en España por efecto del cambio climático, pp. 469-524. Ministerio de Medio Ambiente, Madrid.

Chappell, J., A. Chivas, E. Wallensky, H.A. Polach and P. Aharon.-1983. Holocene palaeo-environmental changes, central to north Great Barrier Reef inner zone. B.M.R. J. Aust. Geol. Geophys., 8: 223-235.

Checa, A., J.I. Díaz, M. Farrán and A. Maldonado. - 1988. Sistemas deltaicos holocenos de los ríos Llobregat, Besós y Foix: modelos evolutivos transgresivos. Acta Geol. Hisp., 23: 241-255.

Chiocci, F.L., G. Ercilla and J. Torres. - 1997. Stratal architecture of Western Mediterranean Margins as the result of the stacking of Quaternary lowstand deposits below 'glacio-eustatic fluctuation base-level'. Sed. Geol., 112(3-4): 195-217.

Díaz, J.I. and A. Maldonado. - 1990. Transgressive sand bodies on the Maresme continental-shelf, western Mediterranean-sea. Mar. Geol., 91(1-2): 53-72.

Díaz, J.I. and G. Ercilla. - 1993. Holocene depositional history of the Fluvia-Muga prodelta (Northwestern Mediterranean Sea). Mar. Geol., 111: 83-92.

Donoghue, J.F. - 1993. Late Wisconsinian and Holocene depositional history, northeastern Gulf of Mexico. Mar. Geol., 154: 383-398.

Durán, R., A.M. Bernabeu, B. Alonso, M. Nuez and M. Moyés. 2007. Seguimiento de la zona de dragado frente al puerto de El Masnou (Costa del Maresme, Catalunya). IX Jornadas Españolas de Costas y Puertos, Comunicaciones, pp. 111-112.

Durán, R., M. Nuez, B. Alonso, G. Ercilla, F. Estrada, D. Casas and M. Farrán. - 2008. Assessment of sand trapped by coastal structures towards better management. El Masnou (Maresme, Catalunya). Geotemas, 10: 511-514.

Ercilla, G., M. Farrán, B. Alonso and J.I. Díaz - 1994. Pleistocene progradational growth-pattern of the northern Catalonia continental-shelf (northwestern Mediterranean. Geo-Mar. Let. 14(4): 264-271.

Ercilla, G., J.I. Díaz, B. Alonso and M. Farrán. - 1995. Late Pleistocene-Holocene sedimentary evolution of the northern Catalonia continental-shelf (northwestern Mediterranean-sea). Cont Shelf Res., 15(11-12): 1435-1451.

Ercilla G. and B. Alonso. - 1996. Quaternary siliciclastic sequence stratigraphy of western Mediterranean passive and tectonically active margins: the role of global versus local controlling factors. J. Geol. Soc., 117: 125-137.

Farrán, M. and A. Maldonado. - 1990. The Ebro continental shelf: Quaternary seismic stratigraphy and growth patterns. In: C.H. Nelson and A. Maldonado (eds.), Marine Geology of the Ebro continental Margin, Northwestern Mediterranean Sea. Mar. Geol., 95: 289-312.

Fernández-Salas, L.M. - 2008. Los depósitos del Holoceno Superior en la plataforma continental del sur de la Península Ibérica: caracterización morfológica y estratigráfica. Ph.D. thesis, Univ. Cádiz.

Fernández-Salas, L.M., F. Lobo, F.J. Hernández-Molina, L. Somoza, J. Rodero, V. Díaz del Rio and A. Maldonado. - 2003. High-resolution architecture of late Holocene highstand prodeltaic deposits from southern Spain: the imprint of high-frequency climatic and relative sea-level changes. Cont. Shelf Res., 23(11-
13): $1037-1054$

Fernández-Salas, L.M., F. Lobo, J.L. Sanz, V. Díaz del Rio, M.C. Garcia and I. Moreno. - 2007. Morphometric analysis and genetic implications of pro-deltaic sea-floor undulations in the northern Alboran Sea margin, western Mediterranean Basin. Mar. Geol., 243(1-4): 31-56.

Flos, J. - 1985. The driving machine. In: R. Margalef (ed.), Key Environments. Western Mediterranean. pp. 60-90. Oxford, Pergamon.

Font, J., J. Salat and J. Tintoré. - 1988. Permanent features of the circulation of the Catalan Sea. Oceanol. Acta, 9: 51-57

Gàmez, D. - 2007. Sequence stratigraphy as a tool for a water resources management in alluvial coastal aquifers: application to the Llobregat delta (Barcelona, Spain). Ph.D. thesis, Univ. Politècnica de Catalunya.

García, M., B. Alonso, G. Ercilla and E. Gràcia. - 2006. The Tributary Valley Systems of the Almeria Canyon (Alboran Sea, SW Mediterranean): sedimentary Architecture. Mar. Geol., 226: 207-223

Goy, J.L., C. Zazo, C.J. Dabrio, J. Lario, F. Borja, F. Sierro and J.A. Flores. - 1996. Global and regional factors controlling changes of coastlines in southern Iberia during the Holocene. Quaternary Sc. Rev., 15 (3-4): 1-8.

Goy, J.L., C. Zazo and C.J. Dabrio. - 2003. A beach-ridge progradation complex reflecting periodical sea-level and climate variability during the Holocene (Gulf of Almería, Western Mediterranean). Geomorphology, 50: 251-268.

Gracia, V., F. Collado, M. García and M. Monso. - 1989. Análisis y propuesta de soluciones para estabilizar el delta del Ebro: clima y oleaje. LT-2/5. Direcció General de Ports i Costes, editor, $120 \mathrm{pp}$.

Gutiérrez Mas, J.M., J.P. Moral, A. Sánchez, S. Domínguez and J.J. Muñoz Pérez. - 2003. Multicycle sediments on the continental shelf of Cádiz (SW Spain). Estuar. Coast. Shelf Sci., 57: 667-677.

Hernández-Molina, F.J., L. Somoza, J. Rey and L. Pomar. - 1994. Late Pleistocene-Holocene sediments on the Spanish continental shelves: Model for very high resolution sequence stratigraphy. Mar. Geol., 120 (3-4): 129-174.

Hernández-Molina, F.J., L.M. Fernández-Salas, F. Lobo, L. Somoza, V. Díaz-del-Río and J.M. Alveirinho Diaz. - 2000. The infralittoral prograding wedge: a new large-scale progradational sedimentary body in shallow marine environments. Geo-Mar. Let., 20: 109-117.

Larcombe, P., R.M. Carte, J. Dye, M.K. Gagan and D.P. Johnson.-1995. New evidence for episodic post-glacial sea-level rise, central Great Barrier Reef, Australia. Mar. Geol., 127: 1-44.

Lobo, F. F.J. Hernández-Molina., L. Somoza and V. Díaz del Río. -2001 . The sedimentary record of the post-glacial transgression on the Gulf of Cadiz continental shelf (southwest Spain). Mar. Geol, 178(1-4): 171-195.

Lobo, F., F.J. Hernández-Molina., L. Somoza., V. Díaz del Río and J.M.A. Dias. - 2002. Seismic stratigraphic evidence of an upper Pleistocene TST to HST complex on the Gulf of Cadiz continental shelf (southwest Iberian Peninsula). Geo-Mar. Let., 22(2): 95-107.

Marqués, M.A. and A. Juliá. - 1983. Fluvià and Muga delta plain: geomorphological features and evolution (Empordà-Gulf of Roses). In: M.A. Marqués (ed.), Symposium on Man's Impact on Coastal Environment. IGU Commission on the Coastal Environment, pp. 7-30.

Marqués, M.A. and A. Juliá. - 1986. Fluvià and Muga delta plain geomorphological features and evolution: Alt Empordà-Gulf of Roses. Thalassas, 4: 123-134.

Medialdea, J., A. Maldonado, B. Alonso, J.I. Díaz, M. Farrán, S. Giró, J.T. Vázquez, E. Sainz-Amor, A. Martínez and T. Medialdea. - 1986. Mapa Geológico de la Plataforma Continental Española y Zonas Adyacentes. E 1:200.000. Instituto Geológico y Minero de España, Memoria y Hojas 41 and 42, TortosaTarragona, Madrid.

Medialdea, J., A. Maldonado, J.I. Díaz, C. Escutia, M. Farrán, S. Giró, T. Medialdea, M. Serra and J.T. Vázquez. - 1989. Mapa Geológico de la Plataforma Continental Española y Zonas Adyacentes. Escala 1:200.000. Memoria y Hojas no 35-42E, Barcelona, Madrid.

Millot, C. - 1999. Circulation in the Western Mediterranean Sea. J. Mar. Syst., 20: 423-442.

Mulder, T. and J.P.M. Syvitski. - 1995. Turbidity currents gener- 
ated at river mouths during exceptional discharges to the world oceans. J. Geol., 103: 285-299.

Muñoz-Pérez, J.J., J.M. Gutiérrez-Mas, J.M. Parrado, and L. Moreno. - 1999. Sediment transport velocity by tracer experiment at Regla Beach (Spain). Journal of Waterway, Port, Coastal, and Ocean Engineering. November/December, 332-335.

Nuez, M., R. Durán, B. Alonso, G. Ercilla, F. Estrada, D. Casas and M. Farrán. - 2008. A morphological evolution model of the sandy coastline Premià - El Masnou (NE Spain). Geotemas, 10: 643-646

Ojeda, E. and J. Guillén. - 2006. Monitoring beach nourishment based on detailed observations with video measurements. $J$. Coast. Res., SI 48: 100-106.

Palanques, A. and J. Guillén. - 1995. The Ebro delta coastal change: natural and human factors. In: MEDCOAST 95. Ed: E. Özhan, pp. 897-909.

Pascual, A., O. Weber, J. Rodríguez-Lazaro, J.M. Jouanneaux and M. Pujos. - 1998. Le comblement de la ría de Gernika (Golfe de Gascogne) à Holocène terminal. Oceanol. Acta, 21(2): 263-269.

Parrado Román, J.M., J.M. Gutiérrez Mas and M. Achab. - 1996. Determinación de direcciones de corrientes mediante el análisis de "formas de fondo" en la Bahía de Cádiz. Geogaceta, 20 (2): 114-117.

Somoza L., A. Barnolas, A. Arasa, A. Maestro, J. Rees and F.J. Hernández-Molina. - 1998. Architectural stacking patterns of the Ebro Delta controlled by Holocene high-frequency eustatic fluctuations, delta-lobe switching and subsidence processes. Sed. Geol., 117 (1-2): 11-32.

Sorribas, J. - 1991. Dinàmica del litoral del Baix Maresme: procesos y cuantificació. Tesis de Licenciatura, Univ. Barcelona.
Swift D.J.P. and J.A. Thorne. -1991. Sedimentation on continental margins: a general model for shelf sedimentation. In: D.J.P. Swift, G.F. Oertel, R.W. Tillman and J.A. Thorne (eds.), Shelf Sand and Sandstone Bodies. Geometry, Facies and Sequence Stratigraphy. Spec. Publs. Int. Ass. Sediment, 14: 3-31.

Trincardi, F. and J.P.N. Syvitsky. - 2005. Editorial. Advances on our understanding of delta/prodelta environments: A focus on southern European margins. Special Issue. Mediterranean Prodelta Systems. Mar. Geol., 222-223: 1-5.

Van Andel, T.H. and J. Laborel. - 1964. Relative high sea level stand near Recife, Brazil. Science, 154: 580-581.

Villares, M. - 1999. Percepció dels impactes estètics i medioambientals de la regeneració de platges. Ph.D. thesis, Univ. Barcelona.

Warner, A.G. and D.J. Stanley. - 1995. Sea-level change as critical factor in development of basin margin sequences: new evidence from Late Quaternary records. J. Coast. Res., 17: 231-240.

Zazo, C., J.L. Goy, L. Somoza, C.J. Dabrio, G. Belloumini, S. Improta, J. Lario, T. Bardají and P.G. Silva. - 1994. Holocene sequence of sea-level fluctuations in relation to climatic trends in the Atlantic-Mediterranean linkage coast. J. Coast. Res., 10: 933-945.

Zazo, C., J.L. Goy, J. Lario and P.G. Silva. - 1996. Littoral zone and rapid climatic changes during the last 20,000 years. The Iberian study case. Z. Geomorph., 102: 119-134.

Scient. ed.: A. Palanques.

Received September 3, 2008. Accepted May 18, 2009.

Published online December 9, 2009. 